\title{
ANALYSIS OF THE INFORMATION COMPONENT OF MARKETING TERRITORIAL STRATEGIES
}

\section{Krystyna Tarasova ${ }^{1}$ \\ Kateryna Semenova ${ }^{2}$}

DOI: https://doi.org/10.30525/978-9934-26-049-0-12

Abstract. The purpose of the article is to analyze the effectiveness of the information component for popularizing the territory brand. In modern conditions, the mobility of people and capital has reached such a level that a well-thought-out branding of the territory allows it to actively compete for resources, investment, skilled labor, partners, and so on. Therefore, the territories need to have their own identity and actively promote it. The importance of creating and promoting a brand is confirmed by both international brand ratings and the results of the development of territories after the implementation of a successfully developed brand.

Territory branding helps to transform a country or a separate region from a geographical unit into a full-fledged product that has its own value.

The work shows that the creation of an effective brand of a territory is a complex mechanism that includes a system of principles, adherence to which allows one to create a brand that reflects the unique characteristics of the territory, its features and attractiveness. Additionally, a successful brand of a territory can become the basis for effective brands of goods and services.

The article analyzes the effective and ineffective brands of territories around the world. Based on this, it was concluded that for the marketing strategy of the territory to be successful, it is necessary to equally involve representatives of government, business and citizens themselves.

An important component of promoting the brand of the territory, like any other product, is the effective dissemination of information about it to the target audience. The Internet has huge opportunities for this as one of the cheapest and easiest ways to disseminate information.

\footnotetext{
${ }^{1}$ Candidate of Economic Sciences, Associate Professor at Department of Marketing, Odessa National Economic University, Ukraine

${ }^{2}$ Candidate of Economic Sciences,

Associate Professor at Department of Economic Analysis,

Odessa National Economic University, Ukraine
}

(C) Krystyna Tarasova, Kateryna Semenova 
The analysis of data for 2000-2020 carried out in the work showed that the share of Internet users in the world is constantly growing. In developing countries, it tends to have accelerated growth, that according to the prognosis will continue its being in the nearest future. At the same time, the main users of the networks are able-bodied and paying people aged 20 to 39 years, whose share is more than $50 \%$ of the world's population. Therefore, promoting the brand of territory using Internet technologies has undeniable advantages over other methods of promoting goods.

In order to attract solvent buyers, the territory must be recognizable, have a competitive and attractive Internet portal. The analysis carried out in the work showed that the websites of the Ukrainian territorial units have a number of short-comings in comparison with the leading European practices. Therefore, the authorities should actively involve professional marketers to develop competitive brands, which will ultimately help the Ukrainian territories to fight equally for resources and capital. In addition, the development of the official site of the territory with the popularization of working enterprises and industries can give an impetus to attracting investment in business.

\section{Introduction}

In today's world, along with personal and corporate brands, the concept of "territory brand" has become enormous. The rivalry of cities, regions and countries for resources transforms them from geographical units into full-fledged goods that have their value and properties. Therefore, there is a need in the territories to have an identity and be able to tell about it.

The mobility of people, capital and ideas in the world is more intense than ever before. Therefore, under conditions of well-thought-out territorial marketing and branding, territories have the opportunity to compete with dignity for resources, investments, residents and partners. The country's position in the world is formed not only collectively at the national level, but also through regions and municipalities.

The importance of developing territories' branding is also confirmed by vari-ous international brand ratings. The most famous one is The Future Brand Country Index. This index measures the strength of perception of countries around the world and reorders the World Bank Top 75 countries by GDP according to the strength of perception. The index provides valuable 
insights for professional brand managers looking to leverage country associations for corporate and consumer brands [1, p. 25]. Experience from branding research shows that confidence in the stability and reputation of territory has a huge impact on its perception and influences basic decisions regarding investment, shopping, tourism and business.

To compile a rating of countries, The Future Brand Country Index uses a whole system of 22 indicators, which includes infrastructure features, cost of money, level of health and education, political freedoms, historical heritage, and so on. The combination of all these factors determines the country's rating and its reputation in the international arena.

According to 2020 indicators, Ukraine ranks 71st out of 75 (74 in 2019), sig-nificantly lagging behind such countries as Colombia, Iran, India, Vietnam, Peru and Ecuador. This indicates that the creation of logo and slogan, which were developed in 2018, are completely insufficient for the brand of our country to become not only recognizable but also to bring dividends. At the same time, one cannot say that nothing is being done in the country in this direction.

The decentralization reform in Ukraine has given territorial units additional strength and emphasized their importance, which will only grow in the future. We are convinced that not only the country itself but also each of its territorial units need a marketing strategy and the formation and promotion of its brand.

This will help not only to declare its uniqueness but also effectively promote economic development.

For example, the city of Kryvyi Rih, where the marketing strategy has been successfully implemented since 2014, has become a leader in Dnipropetrovsk region in attracting foreign investment in the city's economy: in 2019, the city received $\$ 1.3$ billion dollars from 26 countries. Vinnytsia has been demonstrating strong dynamics in attracting investments over the last few years, opening one large production enterprise after another, where thousands of people are employed. Energodar also has something to boast about: the American company Amazon intends to invest \$440 million dollars to build an industrial park in the city and equip its information processing centers there. This will ensure the creation of approximately 2,000 new jobs [2, p. 6].

Practice shows that the skillful positioning of the territory and the creation of its image in the minds of stakeholders, brand development, is the key to its 
successful development. One of the successful practices of territorial branding is brand promotion using information and communication technologies.

The aim of the study is to analyze the feasibility of creating and using territorial branding to promote a territory as a special type of product. Using the information component as one of the most effective methods of brand popularization.

The research methodology is based on the use of a system of analytical techniques and research methods, namely: the method of comparison; methods of analysis and synthesis; methods of dynamics analysis; methods of trend modeling and forecasting.

The objectives of the study are as follows:

- To reveal the basic principles of construction of branding of the territory.

- To identify the main communication elements of the territory brand.

- To prove the benefits of using Internet resources to increase the efficiency of the territory brand.

- To identify trends in the share of Internet users in the world and develop a forecast for the medium term.

- To prove that the key to attracting tourist and cash flows to the territory in modern conditions are active Internet users.

The logic of the study is as follows. Firstly, the essence and principles of the territory branding and its main communication elements are considered. Further analysis of successful and unsuccessful brands of the territories is carried out. The advantages of using Internet resources to increase branding efficiency are proved. The analysis of tendencies of the number of netizens' change is done. Based on those changes, the forecast is developed. Finally, based on the analysis of the age structure of tourists, it is proved that active Internet users can be the key to attracting tourist and cash flows to the territory of Ukraine in general and the Odessa region in particular.

\section{The essence and principles of territory branding}

There are many stereotypes about countries or regions in modern society. They increase the recognizability and uniqueness of the territory. For example, France is known as a country of romance and delicacies, Britain - as a country of tea and rainy weather. Switzerland is the cradle of reliable banks and quality watches, and Brazil is remembered as a country of carnivals and football. But all this is just the tip of the iceberg called «branding». 
The brand of the territory is a multidimensional construct consisting of functional, emotional and material elements, which together create a unique set of associations with a place in the minds of people [3, p. 508].

On the one hand, the bearer of the brand of the territory is the territory itself. But on the other hand, a brand is an impression of a territory or a set of ideas about it. In this case, the bearer of the brand is an external «consumer» of the territory - an investor, a potential resident, a tourist.

Thus, we conclude that the brand of a territory is something «in the middle» between its vision from the inside and its perception from the outside.

The brand of the territory exists in the representation of different groups of the target audience as a complex of images, associations and expectations. It is a rational or emotional value that is formed in the process of relationship with the consumer. The brand reflects the unique characteristics of the territory, its charms, which have gained public recognition and have a stable demand among the target audience. Successful brands are always dynamic. They not only show the current state of the territory, but also give an idea of what it will be like in the future.

The brand creates relationships with all groups of the target audience, forms emotional attachment and loyalty. Consumer perceptions of the idea and brand values of the territory form the basis of its image. If these ideas are formed correctly and the final image reflects the territorial identity as fully as possible, adequately and positively, then we can assume that the brand of the territory has worked successfully.

Marketing experts say that when compiling the brand of the territory it is necessary to take into account two parameters: visual and verbal attributes (Figure 1) [2; 3].

Related concepts are territorial identity and the image of the territory.

An effective brand becomes a guarantor of a premium price, a growing flow of buyers (customers), their love and their loyalty.

There is a certain mechanism for creating an effective brand, which includes the following principles:

1. Formalization and elaboration of business ideas and tasks of the future brand. Elaboration of the goals of the brand and its creation.

2. Analysis of the market, resources and opportunities, trends and preferences, segmentation.

3. Creative development of concepts (including alternative). 


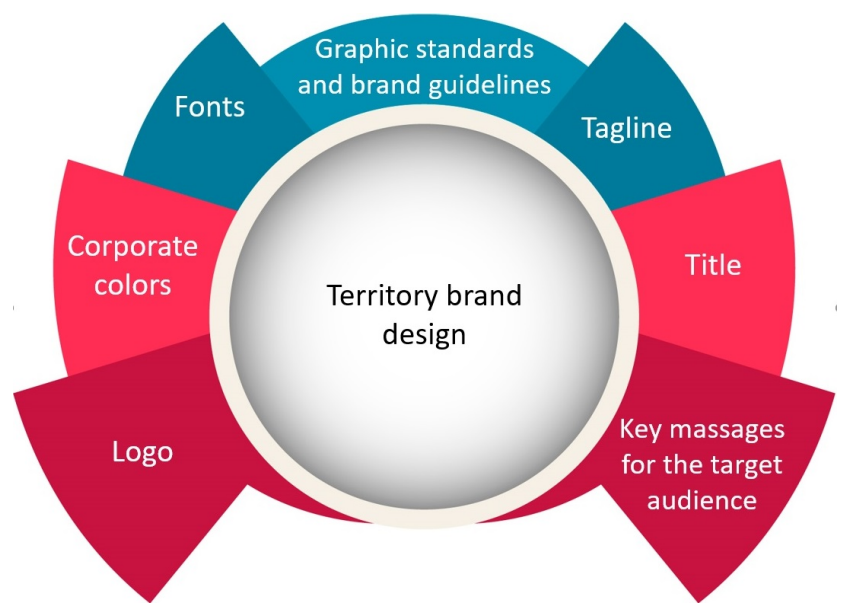

Figure 1. Territory brand design concept

4. Verification of the name for patent purity and ensuring the legal protection of the trademark.

5 . Brand visualization.

6. Brand positioning.

7. Brand management.

This mechanism, in general, is suitable for both a product brand and a service brand, personal brand, organization brand and so on [2, p. 17].

The brand of the territory is formed based on a pronounced positive image of the territory and is the highest manifestation of emotional consumer preferences.

Thus, the brand of the territory is the unity of Idea, Values, Brand Design.

An effective brand of a territory can form the basis for the creation of effective brands of goods and services, for example, car brands of Malibu (Chevrolet), of Ta-coma (Toyota), of Dakota (Dodge), of Santa Fe and Tucson (Hyundai) and numerous models of the Seat brand (Leon, Cordoba, Toledo, etc.). It can also become a guarantee of the quality of many goods and services (made in Germany - for cars, made in Japan for technology, Swiss-made - for watches). Such concepts as "Cuban cigars", "Italian clothes", "Egyptian cotton" have become household names. 


\section{The main communication elements of the territory brand}

Territory marketing is not a one-time project or a list of actions. It is a certain approach and attitude. This process is as permanent as site management or strategic planning. Experience shows that effective marketing measures are not accidental. They are part of a comprehensive and consistent strategy.

The preparation of the marketing strategy has nine stages:

1. Analysis of the situation.

2. Defining goals.

3. Market segmentation.

4. Conducting market research. Research of needs and desires of each target group.

5. Positioning and branding. Formation of the concept of target image and brand of the territory.

6. Choosing a set of marketing tools. Choosing marketing communication channels.

7. Development of indicators for marketing activities evaluation.

8. Budget preparation.

9. Development of strategy and plan for its implementation. Once adopted, the strategy becomes a policy of the territory and can be financed from its budget.

Despite the recommended methodology, there is no single successful approach. Each city or region has its unique conditions and resources and contributes an indispensable share of creativity.

According to the methodology of the PROMIS Project, it is necessary to equally involve representatives of government, business and citizens in the development and implementation of the marketing strategy of the territory [2, p. 20]. Everyone contributes to the process. Officials provide administrative resources, coordinate and lobby the interests of the territory. The business shares expertise provides financial and personnel support. Residents can provide ideas and political support. None of the commercial, public or state institutions has sufficient resources, authority and professionalism to market and brand the territory independently.

Thus, the marketing of the territory is a collective work and a field for the im-plementation of social partnership. To carry out successful marketing activities, it is important to identify all possible partners, ensure interaction 
between them and cooperation with institutions and organizations at the national and international levels.

An action plan for the implementation of the marketing strategy should be developed and implemented gradually, providing an opportunity to assess current results and the need for further changes.

A marketing strategy can rarely be implemented in its original form. It can and should be adjusted in response to continuous changes in the environment. It is recommended to review the developed strategy every year. Experts from various fields should be involved in monitoring the implementation of the strategy for the sake of completeness and constructive judgments. The positive image of the territory created as a result of marketing and branding is a long-term tool designed for a strategic perspective.

The most important stage of preparing a marketing strategy is the sixth stage - the choice of the type of marketing communications. The brand of the territory is promoted with the help of information disseminated about it, the corresponding indices and ratings. The newly formed opinion should correspond with the strategic objectives of the territory's development and promote the attraction of those economic entities, organizations and people, as well as resources and orders that are in demand by the territory, are necessary and useful for its development.

The main communication elements of territory branding include:

1. Symbols of the territory - flag, coat of arms, anthem.

2. Internet (official website of the territory, portal, forums, posters of events, reference information, dating site, etc.).

3. Image publications and interviews in mass media of national, regional and local scales.

4. Organization of general territorial events.

5. Outdoor advertising.

6. Information brochures, catalogs, souvenirs of the city that reflect the general concept of the territory [4, p. 12].

Thus, in practice, branding a territory means organizing specific large and small projects for each of the six branding areas. The larger is the number of such projects, the more it is likely to create a positive brand. That brand is a force field that forms a strong and positive impression of the territory as well as the "correct" idea of its identity. 
With the rapid development and spread of Internet technologies, another new type of communication is gaining great value for the development of urban identity and its reflection in the image of the territory. It is the so-called public diplomacy. The term appeared 60 years ago. During those times in the United States, public diplomacy began to denote international political events with massive public participation: international peace marches, student exchanges, teleconferences, actions of specialized public organizations, peace embassies, etc.

Social media has become the fastest growing area of public diplomacy today. The speed of spread and the scale of popularity of social media for marketing purposes suggests that in the coming years it will become one of the main types of marketing communication in territorial marketing programs, including branding. An active role will be played by young people, who, on the one hand, are the most "responsive" to branding initiatives for their city, and on the other, they are most immersed in the Web.

Discussion and promotion of territorial brand ideas in the blogosphere as well as on Twitter, LinkedIn, Facebook, Vkontakte, YouTube, MySpace Facebook are tools of great potential influence on the formation and development of territorial brands. For example Facebook has 2.5 billion active users per month or 1.6 billion daily active people. According to experts 752 thousand Ukrainians visit Facebook every week, and the total number of users is approaching 15 million [5].

The Internet provides territories with vast and varied opportunities to express themselves to their target groups. These opportunities include maintaining the territory's website, creating chats and forums to exchange ideas and opinions with the target audience, establishing feedback with them, creating a database using digital interviews and online programs. In this sense, new communication technologies offer important functions in the branding process.

The main rule when transforming a product or service into a brand is the effective transmission of all information about this product or service to the target audience. Any information about the territory and its attractions is promoted through the Internet through a variety of means. Subsequently, the site will turn into a brand and will influence decision-making.

Online brands are invisible until you enter a brand name. If you don't know the brand name and how it is spelled, no sale will happen. Therefore, 
online name recognition is essential. During the territorial brand promotion phase on the Internet, users should easily find the territory website to be placed as a brand. Based on this fact, many cities register URL addresses such as www.paris.org.

Territories that want to become online brands should focus on the services provided by the Internet. Consumers expect service from the website they visit, from hotel reservations to car rental, from weather forecasts to city cultural events. Therefore, such services should be available to consumers online. The quality and reality of the services provided are very important for building the brand and the website that offers them. Online services should also be illustrated with an appropriate visual demonstration. A high-quality representation of many elements of any territory, such as an interactive map, hotel contacts, online reservations, information about city authorities and institutions, is extremely important in the process of branding a territory on the Internet.

The Internet has great potential as a method of promoting a territorial brand. This method is cheaper compared to other advertising and promotional media, espe-cially if you take into account that information on the Internet can be accessed 24 hours a day from anywhere in the world.

\section{Promotion of the territory via Internet}

In the modern world, territories are becoming full-fledged players in the online information space, both consuming and producing large amounts of information, implementing their communication strategies. The territories test ideas for local development, form active community groups, conduct explanatory work on unpopular decisions, collect information about accidents and threats to public safety. They compete with other territories for tourists, investors and even residents. Territories develop partnerships with other web resources and offline initiatives. They provide electronic services. All these are informational functions of the territorial authorities, which increase the efficiency of the activities of all divisions of the municipality. Despite the variety of unofficial - public and commercial - web resources (portals and forums, travel sites, social networks, public initiatives, etc.), the local government should remain a key conductor of the territory's information policy, and integrator of all information flows. In comparison with the leading European practices and trends in the official websites of 
Ukrainian territories in the context of their branding, the following main disadvantages can be distinguished:

- Poorly structured content.

- "Egocentricity". The initial position and starting point are the authorities, not the user, the audience.

- The prevalence of cumbersome and redundant information, long reference information and historical and geographical essays.

- Lack of adaptation of websites for different segments of the target audience (residents, tourists, business, investors).

- Low level of provision of electronic services.

- Lack of a proactive approach in using websites as a platform for promoting government initiatives, forming support groups and other social interaction.

- Absolute search engine inefficiency of websites.

- Ignorance of the potential of tools for search engine optimization, increasing popularity and expanding the audience.

- Mostly outdated design.

- Lack of high-quality visual material about the territory (for example, art photographs).

At the same time, most of the best foreign practices say that a modern Internet portal is the main way to promote a territory's brand. This is how the state-of-the-art Internet portal IAmsterdam (www.iamsterdam.com) was created in order to purposefully meet the requirements of foreign tourists and companies. The web portal was developed as part of a joint project of the municipal government, Amsterdam Partners, the Amsterdam Uitburo, Amsterdam's Tourism and the Conference Bureau.

The information on the website is divided into blocks that are targeted at different target audiences. On the website, one can find information about Amsterdam itself, the peculiarities of life in it, the main attractions, information about active rest in the city. The site will help to find a job, tell about the peculiarities of doing business in Amsterdam, provide information to investors (Figure 2).

Timely response to modern challenges is also an important detail. The site contains details of a safe stay in the city, including the current spread of coronavirus infection.

Copenhagen is an identical example. The city is open in every sense: to tourists, business, investments, adventures, etc. The positioning of the 


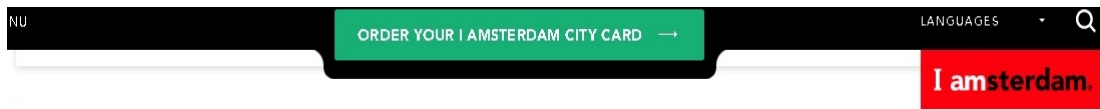

| Your guide to living, working \& investing in Amsterdam

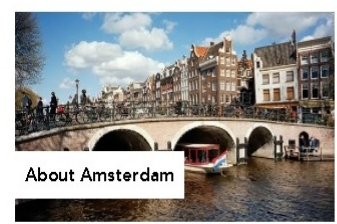

Learn all about Amsterdam, including its rich history, the development of its tolerant society and how it became such a bustling hub of commerce.

About Amsterdam

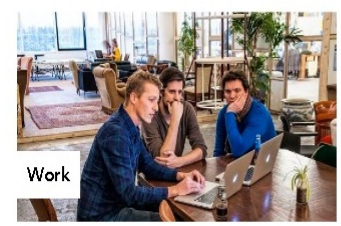

Take your career to the next level with Amsterdam's wide variety of job opportunities across a range of sectors. Work in Amsterdam

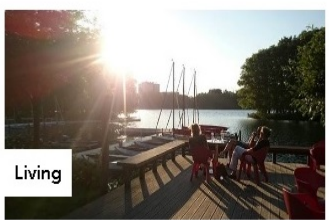

Look up official information for expats about permits, registration, visas, housing, healthcare, the $30 \%$ tax ruling and more. Living in Amsterdam

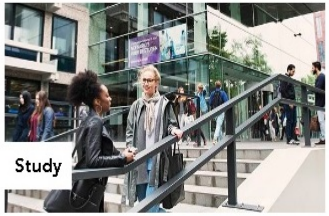

Study at one of Amsterdam's leading universities, colleges and educational institutions. Apply for bachelor, master and $\mathrm{PhD}$ courses in English.

Study in Amsterdam

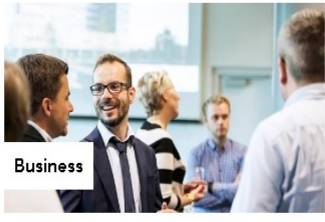

Be part of a thriving business ecosystem alongside cutting-edge startups, international corporations, social entrepreneurs and renowned innovation. Do business in Amsterdam

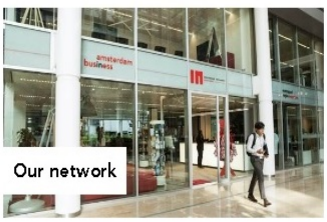

Tap into our world-class support network for businesses, startups, locals, international newcomers, media professionals and more.

Connect with our network

\section{Figure 2. The main headings of the city portal of Amsterdam}

city consists of three keys - the comfort of life, friendliness and tolerance. These are the qualities with which residents of the city associate themselves. The logo is made in the form of a button with the OPEN inscription. The website (www.copenhagenopen.net) will tell you about interesting events, the history of the city, show you where you can eat and stay overnight.

At the same time, there are less traditional examples of territory branding using information technologies. The most striking example of this unconventional branding is the Italian province of Molise, whose branding has become a cultural phenomenon.

Molise is a small province located to the east of Rome. Until recently it was known that it did not exist. That is, technically, of course. It exists 
as one of the 20 official regions of Italy. Molise has the same status as Tuscany, Lombardy or Piedmont. Regional and national elections are held here.

However, throughout the history of Italy, Molise was located on the outskirts. And despite the rich resource potential in the form of mountains and the sea, Molise remained the least known region of the country.

A few years ago on the Internet, people started posting the hashtag \#ilmolise-nonesiste as a joke, making fun of the small size of the region and the relative obscurity in Italy. A real informational wave has risen.

The so-called "Molise conspiracy" has become a cultural phenomenon in Italy, spawning books, songs, videos, theatrical monologues, news articles, posts on social networks with funny memes (Figure 3).

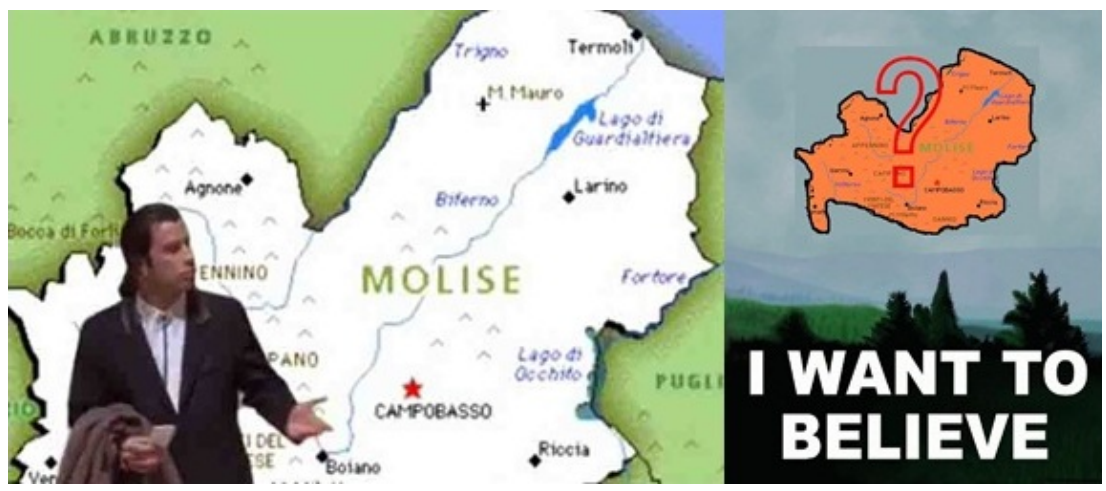

Figure 3. Memes of Molise

Molise has been referenced by everyone from famous actors to former prime minister Matteo Renzi. Since 2015, a YouTube video titled "IL MOLISE NON ESISTE!" has over 1.6 million views, which is more than five times the number of residents of Molise.

The locals decided to take advantage of this hype and soon began to produce and successfully sell T-shirts, mugs and other goods with the inscription "Made in Molise" in this area.

Over the years, the small region has become a national joke in Italy. Now, if a person says that he is from Molise, everyone laughs. Thus, the residents themselves chose the brand of their territory based on a common 
joke. This joke helped to create a whole strategy for promoting the region at the national level only using digital technologies of Internet users.

Foreign marketing history is full of other examples of successful brand development and rebranding of territories. Experts say that Estonia is particularly successful with its corporate font, which is used everywhere, including the country's official web pages. Among the countries, one cannot but mention Canada, Lithuania and Bhutan. Among the cities, London, New York and Las Vegas stand out especially. For example, in 2012, the distribution of the Totally LOND ON brand during the Olympics helped to attract 11.7 billion euros to the city, as well as significantly in-crease the annual tourist traffic.

Numerous unsuccessful examples also show how important it is to approach the positioning of the territory on the market. Like the loud phrase "Good people. Great nation" displayed on the Nigeria country's logo was generally judged (Figure 4).

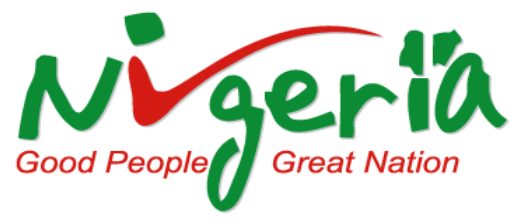

Figure 4. Nigeria's logo

Considering the abundance of pirates, the level of literacy and the number of people living below the poverty line, such a brand is just bewildering. The disad-vantages of branding also lie in the communication component of marketing. The country has more than 130 official websites: 4 dedicated to customs policy and 13 to the features of foreign trade, 5 to the legislative system and so on. It's hard for an external user to figure it out.

A similar situation developed in Uganda, whose slogan until recently was «Gifted by nature». And this even though, that as a result of a twentyyear-long civil war in the country, all the rhinos were destroyed. However, note that the rebranding of the country was nevertheless carried out and now in Uganda there is a completely different visual (Figure 5).

As we mentioned earlier, Ukraine also has its brand, which is part of the large-scale marketing campaign Ukraine NOW. With the support of the 

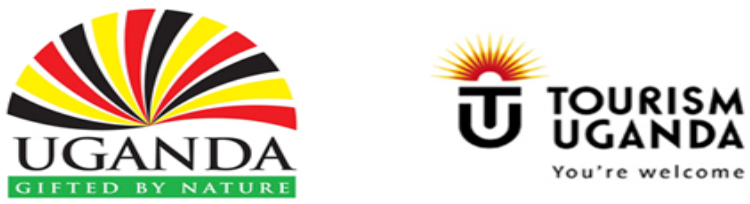

Figure 5. Old and new logos of Uganda

British govern-ment, a study was conducted on how Ukraine was perceived abroad. According to its results, the three most popular associations with Ukraine are "corruption", "revolution" and "fighting".

People who have never been to Ukraine see Ukrainians as closed, aggressive and intolerant. This image is formed mostly from what they see and hear in the news. With such a reputation, it is difficult to attract investment and tourists to the country. But those who have been here at least once change their minds and celebrate the hospitality of Ukrainians, beautiful scenery, culture and architecture. Ukraine's new branding is dynamic, open and positive (Figure 6).

\section{Ukraine $_{\text {NOW }}{ }^{\text {ua }}$}

Figure 6. Ukraine's logo

The authors of the logo tried to "underline" the main word of the message with a yellow marker - NOW. The blue element in shape resembles the notifications we see on social networks. It is a symbol of something new that attracts attention. Ukraine is worth paying attention to now [6].

The minimalism of the logo makes it easy to use. It is built of basic geometric shapes. This allows you to brand anything. Simply styled elements "penetrate" into any object.

At the same time in the regional context of the branding process in Ukraine, there are not so many promotions. One of the leaders in this regard is the Khmelnytsky region with the slogan "Intersections of Elements and Stories". Quite indicative is the fact that the process of creating the logo and slogan was put to a general vote, where the residents of the region chose one of four options. There is even a specific brand usage order: a list of special fonts, colors and symbols. 
In 2020, the Kherson region was also engaged in brand development referring to the agricultural significance of the region and the painting by Giovanni Stanki (Figure 7).
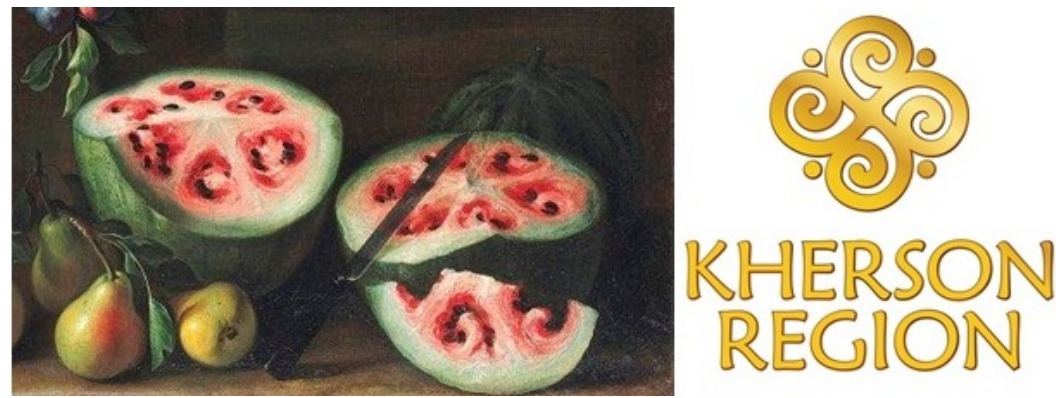

Figure 7. Connection between the logo of the Kherson region and the painting by Giovanni Stanki

At the same time, many regions and cities do not even consider the possibility of creating their brand. One of such territories is the Odessa region in general and the city of Odessa in particular. Having a fairly large reputation in Ukraine and abroad, the authorities never come to a single marketing position and do not try to develop it.

The main branding tools are verbal and visual symbols in both online and of-fline formats. For example, the slogans of the city "Pearl by the Sea", "City of Hu-mor", "Southern Capital of Ukraine" can be verbal. The visual symbols of the city are the coat of arms, the flag, monuments, the Potemkin Stairs, the Opera House.

Placing uniform symbols on billboards, street advertisements, official websites, forums and city portals would help create a unified image and consolidate an attractive image. Improvement of the city portal, following the example of western analogs (Amsterdam, Copenhagen), would also be important.

One of the main proofs of the need for branding territories, especially from the point of view of the information component, is the sphere of tourism. As we have already emphasized earlier, most of the best foreign practices indicate that the main way to promote a territory's brand is a modern Internet portal. It is obvious that its effectiveness largely depends on the number of Internet users in the world and individual regions. 


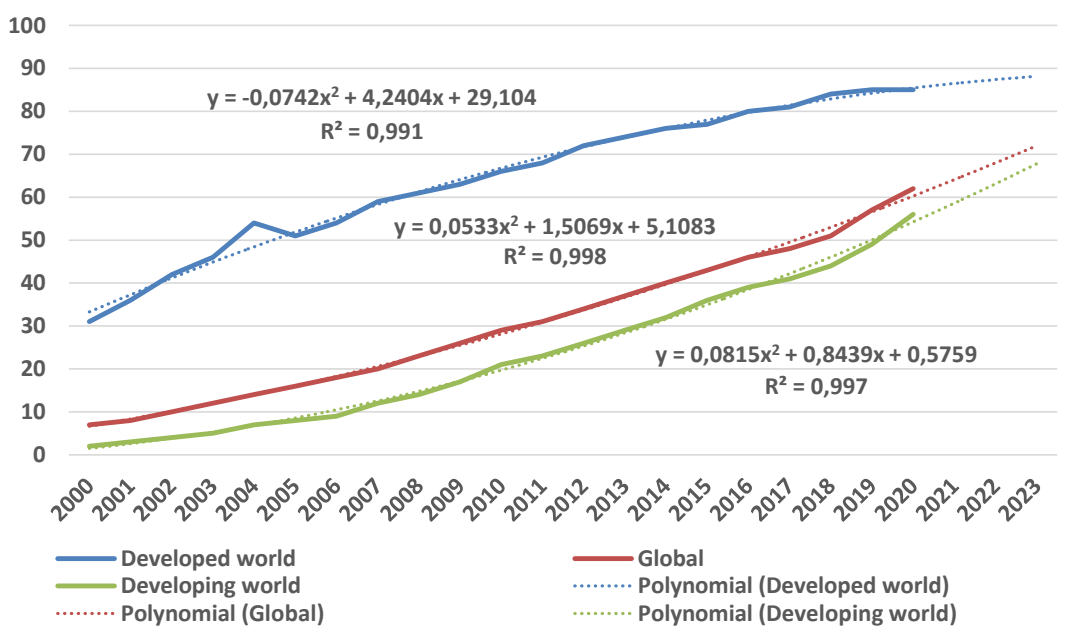

Figure 8. Dynamics of the share of Internet users in the world, \%

The Figure 8 shows the dynamics of the share of netizens in the world during 2000-2020 [7], as well as the constructed trend models.

To identify the trend in the change in the proportion of Internet users, we tested various forms of the trend (linear, logarithmic, power, exponential, 2nd degree polynomial). The analysis showed that polynomials of the 2nd degree most accurately reflect the formed trends. This is evidenced by the determination coefficients of all three trends. They exceed $0.99(99 \%)$.

However, the main trend in the change in the share of Internet users for developed countries shows slow growth. For developing countries and the world as a whole, the trend shows accelerated growth. This dynamic is obvious since the Inter-net has only recently begun to spread actively in developing countries.

Based on the constructed trends, we made a forecast for 2021-2023, in accordance with which it can be expected that the number of Internet users in the medium term will only increase, especially in developing countries.

As a result, it can be expected that the creation of an effective internet brand of Ukraine, as well as its individual cities, which are little known in the world, will lead to the recognition of the country and an increase in tourist flows. 
According to the data of the special project of Delo.ua, Ukraine ranks fifth in the world in terms of growth in the number of tourists. Tourism in 2019 generated $10.4 \%$ of world GDP, or \$ 3.3 trillion dollars [8].

At the same time, $80 \%$ of the tourist turnover was provided by vacationers and only $20 \%$ - by business travelers [9].

Despite the fact that COVID-19 caused an unprecedented crisis in the tourism industry, the share of this sector in Ukraine's GDP increased by $2 \%$ during 2020. Other countries are beginning to rebuild this area. With the fall in the level of panic and the reduction in the total number of cases, many states are beginning to open their borders. There will be a lot of competition to increase the popularity of the industry. An important role in this competition will be played by the factor of popularity of the territory and its brand, including in information networks.

The element of independent tourism without agencies and operators is becoming more and more important when a potential tourist chooses a destination himself. In this choice, he relies heavily on social media. According to the data, the main users of the networks are just able-bodied and paying people aged 20 to 39 years (Figure 9) [10].

If we compare these data with the age structure of tourists (Figure 10), we can assess the importance of promoting the territory using information technology [10].

Marketing research by Condor Ferries has shown that the younger Gen and millennials spend the most on travel. Calling themselves «flashpackers,» they spend about $\$ 3,500$ on the trip and $\$ 60$ a day. Millennials make the most of their vacation - most of them take an average of 35 days of vacation every year. Gen $Z$ travelers travel an average of 29 days a year and, according to surveys, $90 \%$ of them say that social media is the main influence on their international travel decisions. More than half of travelers aged 25-34 spend between $\$ 500$ and $\$ 1,500$ on a weekly trip excluding flights and a third of millennials are willing to spend more than $\$ 5,000$ on vacations [11].

Thus, it is the active Internet users who are the key to attracting tourist flows, as well as funds to the territory.

In the harsh conditions of competition for visitors, an important role can be played by the fact that the place, its brand, and the image in the heads of potential tourists are advertised. The figures obtained by Condor 


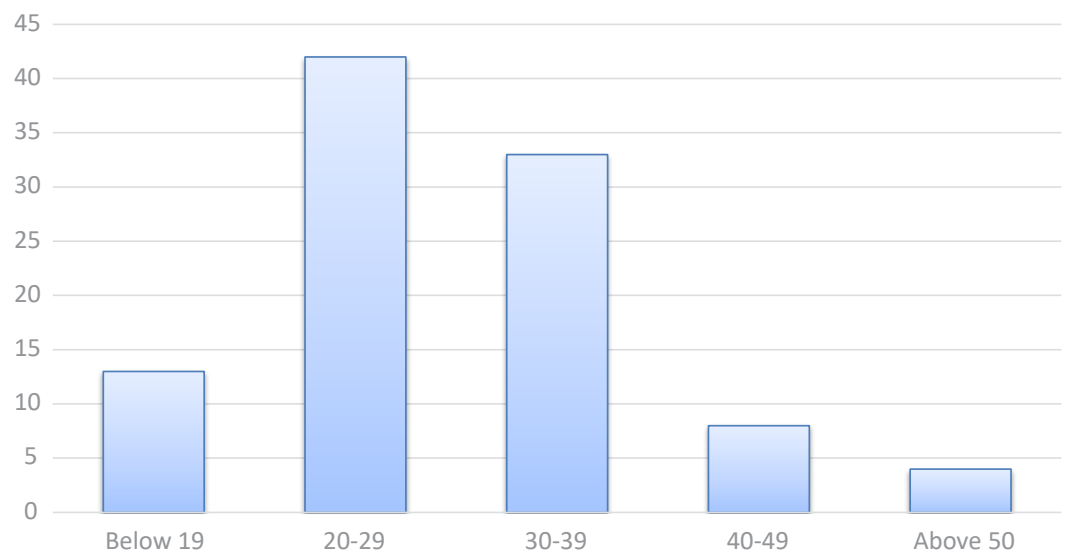

Figure 9. Age structure of netizens, \%

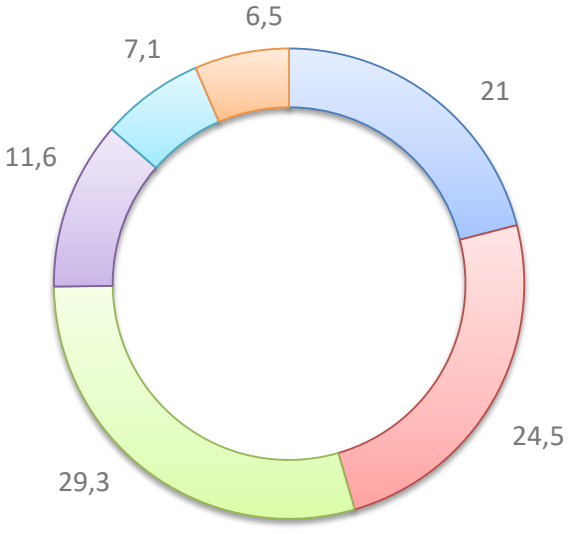

$\square 18-24 \square 25-29 \quad \square 30-39 \square$ 40-49 $\square 50-59 \square$ Over 60

Figure 10. Age structure of tourists, \%

Ferries during the survey clearly illustrate the benefits that "information generation" visitors can bring. Without promoting the image of the territory and not creating its brand, Ukraine in general and its territories in particular may lose potential visitors, both local and foreign. 


\section{Conclusions}

The analysis carried out in the work showed that the development of the territory in the modern conditions of the development of the Internet should encourage the local authorities of certain regions of Ukraine not only to form brands of their territories but also to develop a strategy for their promotion. Websites should be a key tool in this strategy. There is such a thing as the atmosphere of the site. It can be created thanks to the appropriate design, layout, use of audio and video materials. The perception of the website can be improved through the use of multimedia.

Therefore, it is fundamentally important for the authorities to be open to all significant public and commercial initiatives, which can be strengthened with the help of official information channels, first of all - the official website.

In such circumstances, the territory's official website should become:

1. A platform for interaction between the authorities, the community and active public, cultural and business groups and initiatives.

2. A powerful tool for territory marketing for external audiences, first of all, visitors, tourists, investors and the media.

3. Demonstration of the attitude and approaches of local authorities to man-agement, development and interaction with external partners. After reviewing the official website, one can conclude the activity or passivity of the territory's leadership.

The modern website of the territory should fulfill the basic function - the provision of electronic services and information services to citizens in the paradigm of electronic government. According to the slogan on the website of one of the cities, "We serve you online, not in line". Such trends are typical for cities in developed countries of the world with a high level of Internet penetration.

The development of websites for the territories of Ukraine following the example of the best European analogs (Amsterdam, Copenhagen) will help not only to attract tourists and possibly potential visitors for work. The development of an official website with a list of operating enterprises, as well as developing industries, will attract business investment. 


\section{References:}

1. IP FutureBrand (2020) The future brand country index, (electronic journal), vol. 3, p. 83. Retrieved from: https://www.futurebrand.com/uploads/FBCi-2020Assets/FutureBrand-Country-Index-2020.pdf

2. Federation of Canadian Municipalities. Partnership for Urban Development International Technical Assistance Project (2019) Keis-stadi. Brendynh ta marketynh terytorii. U chomu sekret naibilsh uspishnykh mist v Ukraini? [Case study. Branding and marketing of territories. What is the secret of the most successful cities in Ukraine?]. Kyiv: Proekt «Partnerstvo dlia rozvytku mist». City partnership project. (in Ukrainian)

3. Kawaratzis M., Ashworth G.J. (2005) City branding: an effective assertion of identity or transitory marketing trick? Tijdschrift voor Economische en Sociale Geografie, vol. 96, pp. 506-514.

4. Soskin O. I. (ed) (2012) Rol'brendinga gorodov v epokhu peremen [The role of urban branding in an era of change]. Kyiv: Institute of Society Transformation. (in Russian)

5. Site of Statista. Retrieved from: https:/www.statista.com/statistics/264810/ number-of-monthly-active-facebook-users-worldwide/

6. Sait "Banda" [Site of organization "Banda"]. Retrieved from: www.banda.agency/ ukrainenow

7. Site of Our world in data. Retrieved from: https://ourworldindata.org/internet

8. Sait "Delo.ua" [Site of the company Delo.ua]. Retrieved from: https://delo.ua/ econonomyandpoliticsinukraine/destination-ukraine-skolko-ukraina-mozhetzarab-355991/

9. World Travel \& Tourism Council (2019) Travel and tourism. Economic impact 2019. World, London: World Travel \& Tourism Council.

10. Liming Wang, Qi Zhong (2019) Research on the Structures and Features of Netizens' Demand for Popular Science: A Search Data Perspective. China Research Institute for Science Popularization, China, vol. 2, issue 2, pp. 129-150.

11. Site of Condor Ferries. Retrieved from: https://www.condorferries.co.uk/ travel-statistics-by-age-group 